\title{
Calculus teaching and learning in South Korea
}

\author{
Natanael Karjanto \\ Department of Mathematics, University College \\ Sungkyunkwan University,Natural Science Campus \\ Suwon,South Korea \\ natanael@skku.edu \\ Department of Mathematics \\ School of Science and Technology \\ Nazarbayev University \\ Astana, Kazakhstan
}

\begin{abstract}
ABSTRAK
Artikel ini menceritakan pengalaman mengajar mata kuliah Kalkulus untuk mahasiswa tahun pertama di Universitas Sungkyunkwan, salah satu universitas swasta di Korea Selatan. Pendekatan belajar dan mengajarnya merupakan gabungan yang seimbang antara gaya tradisional kuliah yang berpusat pada dosen dan kegiatan lain yang menganjurkan mahasiswa untuk belajar secara aktif dan berperan serta di dalam kelas. Dari pengamatan awal selama beberapa semester, beberapa bukti anekdot menunjukkan bahwa pembelajaran mahasiswa meningkat setelah diterapkannya pendekatan belajar aktif yang berpusat pada mahasiswa, meskipun waktu yang lebih lama pastinya diperlukan untuk mengubah sikap umum mahasiswa dari pelajar yang pasif menjadi pelajar yang aktif.
\end{abstract}

Kata kunci: Mata kuliah Kalkulus, pengajaran dan pembelajaran, pembelajaran aktif, berpusat pada dosen, berpusat pada mahasiswa, matematika tingkat sarjana, Korea Selatan.

\section{ABSTRACT}

This article discusses an experience of teaching Calculus classes for the freshmen students enrolled at Sungkyunkwan University, one of the private universities in South Korea. The teaching and learning approach is a balance combination between the teacher-oriented traditional style of lecturing and other activities that encourage students for active learning and classroom participation. Based on the initial observation during several semesters, some anecdotal evidences show that students' learning is improved after implementing this student-oriented active learning approach, albeit a longer period of time is definitely needed to transform general students' attitude from passive learners to active ones.

Keywords: Calculus course, teaching and learning, active learning, teacher-oriented, student-oriented, undergraduate mathematics, South Korea.

\section{Introduction}

Many countries around the world are concerned with the quality of education of their citizenry, ranging from basic to higher education. A number of international standards have been developed in order to verify and compare the effects of education policies. Several well-known examples of assessments in reading, mathematics, and science literacy amongst others are the Progress in 
International Reading Literacy Study (PIRLS), the Trends in International Mathematics and Science Study (TIMSS), and Program for International Student Assessment (PISA). The first two studies were conducted by the International Association for the Evaluation of Educational Achievement (see IEA [11]) in order to compare students' educational achievements across borders among the participating nations. The latter one is coordinated by the Organization for Economic Cooperation and Development (see OECD [26]) aiming at improving the educational policies and outcomes not only for the OECD member countries but also for other non-OECD participating countries and economies. The assessment results can help educational policy makers to shape their policy making in general and to improve education strategies in particular. Although the assessments are predominantly targeted at the elementary and secondary school levels, it is no doubt that the corresponding results may also reflect the quality of higher education. In the realm of higher and college education, many institutions worldwide develop institutional or nationwide program (or 'visions') in teaching and learning to improve the quality of their higher education.

A lot of resources have been invested into these programs to improve the quality of higher education, for instance by training instructors, tailoring curricula and introducing novel, nontraditional and innovative styles in teaching and learning. Although the conventional-traditional teaching method still remains popular around the globe, pioneer-minded institutions challenge these teaching methods by successfully implementing up-to-date, nontraditional approaches in instruction, teaching and learning. Two well-known examples are problem-based learning (Hmelo-Silver [8], Neville [24]) and guided-discovery (Leutner [21], Shrager and Klahr [33]), for which both are based on constructivist teaching strategies. These two pedagogical approaches can be categorized as active learning activities, methods that provide harmony between the instructor's role and the students' role.

This article describes an author's experience of teaching and learning Calculus in a four-year university in South Korea and the discussion focuses on implementing a mixture teaching and learning methods between teacheroriented and student-oriented approaches. The content of the article is organized as follows. In the following section, the theoretical framework on active learning is laid and the literature is reviewed. In Section 3, brief profiles of South Korea's higher education and Sungkyunkwan University (SKKU) are presented. This university is a private institution in South Korea where the study has been conducted. Next, Section 4 explains the organization of Calculus courses at SKKU. This section describes the course management and the adopted textbook. Section 5 follows with the current practice of Calculus teaching and learning at SKKU. This section also discusses both the existing, traditional teaching method and the one that encourages active learning and student's participation. The final section draws conclusion to our discussion. 


\section{Active Learning}

There is an abundance source of literature on active learning, stimulating active participation, and enhancing critical thinking and the list is not exhaustive. In the context of this article, active learning refers to techniques where students do more than simply listening to a lecture from an instructor. The students are involved in doing some activities, to discover, to process, and to apply information (see McKinney [22]). The author offered several in-class examples of active learning techniques that can be used in both small and large classes, as well as with all level of students, amongst others are collaborative learning group, games, student debates, case study analysis, concept mapping, think-pair-share and student-led review sessions. Other concrete examples on active learning activities can also be found in King [15].

Bonwell and Eison in [2] popularized the approach of active learning for class instruction. They suggested that pupils can work in pairs, discuss the materials while role-playing, debate, engage in case study, take part in cooperative learning, produce short written exercises, and many other activities. Lazarus [19] mentions a number of strategies to stimulate active participation, for instance by questioning techniques and stimulating group discussions. Kim and Kim [13] explore students' participation in online discussions. The authors discover that the participation patterns are mainly influenced by the students' voluntary participation. According to Meyers and Jones [23], active learning is derived from two basic assumptions: learning by nature is an active endeavor and different people learn in different ways. The authors also show that the quantity of learning is enhanced when the students are engaged in active learning. Salter in [32] emphasized that the implementation of problem-based learning techniques can change surface learning into deep learning, memorized knowledge into understanding, etc.

Implementing active learning approach in teaching is not only beneficial for the students, but also useful for instructors, notably the new ones, as addressed by Eison [6]. In particular, an attempt to encourage students who enrolled in Calculus classes to be active learners has been reported, amongst others by (Abramovitz et al. [1], Idris [10], Zhang [41]. It is interesting that even a Calculus textbook specializes on active learning edition has been published recently (Hughes-Hallet et al. [9]). Active learning method has also been implemented not only in Calculus course, but also in other mathematics-related subjects, such as General Physics (Laws et al. [19]) and Engineering Statistics (Kvam [17]). Related to the latter one, an evaluation of an active learning approach in teaching Introductory Statistics class has been reported by Carlson and Winquist in [3]. The review of their article in the context of changed attitudes and improved performance is discussed recently in a newsletter edited by Weiner and Kelly [38].

As mentioned in the preceding article, the focus of this article is to share the author's experience in exerting active learning strategies toward the students 
enrolled in Calculus classes at Sungkyunkwan University (SKKU), a private, four-year university in South Korea. Although this experience has led to some interesting anecdotal evidences, the author is fully convinced that this is not the end of the journey toward improvements in teaching and learning. It is hoped that after experiencing the active learning approach, the students will not only improve their learning skills in the mathematics related subjects, but also will elevate their learning achievements in other subjects along the road during their undergraduate study timeframe and beyond.

In the following section, brief profiles of South Korea's higher education and SKKU are presented.

\section{Brief profiles of South Korea's higher education and Sungkyunkwan University}

\subsection{A brief profile of South Korea's higher education}

Education, including higher education, has a unique place in the South Korean's society. Thanks to its Confucian culture, the society puts a heavy emphasis on the value of gaining education. According to the World Factbook published by the Central Intelligence Agency, the literacy rate in South Korea is $97.9 \%$ (see CIA [5]). The definition of literacy is a person of age 15 and over who can read and write. Although South Korean students often rank extraordinarily in many international competitions, such as mathematics, science and informatics Olympiads as well as comparative assessments, such as TIMSS, PIRLS and PISA, the education system in South Korea is heavily criticized since it put too much emphasis on passive learning and rote memorization. This is one of the motivations to implement active teaching and learning in Calculus class and to conduct this research.

Although some form of higher education has existed continuously in South Korea since the 4th century, many universities have their history dated back prior the Japanese Imperial Period, such as Yonsei University Medical School Gwanghyewon (1885), Ewha Hakdangmission school for girls (1886) and Bosung College (1905), where the latter one is the embryo of Korea University. After its liberation from the Japanese colonial rule in 1945, many of these universities are officially recognized and many more institutions are established: Ewha Womans University and Korea University (1945), Seoul National University, Yonsei University and SKKU (1946). Nowadays, there are more than 370 official higher education institutions in the country, which includes more than 40 national universities, 180 private four-year universities and other types of higher education institutions, including polytechnics, cyberuniversities, two- and three-year junior colleges (Parry and Lee [27]). The advancement rate from secondary school to higher education in South Korea reaches almost $88 \%$ in 2008 , one among the highest in the OECD countries (see Lee [20]). The following subsection discusses a brief profile of SKKU. 


\subsection{A brief profile of Sungkyunkwan University}

Sungkyunkwan University, often abbreviated as SKKU and also known by its nickname in Korean as Seongdae, is a private research university in the Republic of Korea. The university has two campus locations: the Humanities and Social Science Campus in Seoul, the country's capital and the Natural Science Campus in Suwon, which lies about $30 \mathrm{~km}$ south of Seoul and the provincial capital of Gyeonggi-do province. It boasts as the oldest university in the country, and possibly in the peninsula as the historical evidence shows that the chronicle of the university dated back as early as 1398 during the Joseon Dynasty. It is of no surprise that the former slogan of the university is unique origin, unique future'. The literal meaning of 'Sungkyunkwan' itself is 'an institution for building a harmonious society of perfected human beings' (Wikipedia [13]). Fast forwardto 1946, the current modern day university was established after the country's liberation form the Japanese Imperialism. After half a century period, the Samsung Group provided funds tore acquire an almost depleted in resources university foundation in 1996 (SKKU website [34])

Table 1.Sungkyunkwan University's rankings for the past couple of years according to the QS World University ranking, Times of Higher Education (THE) and Academic Ranking of World Universities (ARWU).

\begin{tabular}{|l|l|l|l|l|}
\hline $\begin{array}{c}\text { University } \\
\text { rangkings }\end{array}$ & $\begin{array}{l}2013 \\
\text { International/ } \\
\text { National }\end{array}$ & $\begin{array}{l}2012 \\
\text { International/ } \\
\text { National }\end{array}$ & $\begin{array}{l}2011 \\
\text { International/ } \\
\text { National }\end{array}$ & $\begin{array}{l}2010 \\
\text { International/ } \\
\text { National }\end{array}$ \\
\hline QS & $162 / 6$ & $179 / 6$ & $259 / 7$ & - \\
\hline THE & $201-225 / 6$ & $201-225 / 6$ & $301-350 / 6$ & - \\
\hline ARWU & $201-300 / 2-4$ & $201-300 / 2-4$ & $301-400 / 4-7$ & $301-400 / 5-7$ \\
\hline
\end{tabular}

During the past several years, SKKU and other top universities in South Korea have been steadily showing their existence in the map of higher education worldwide. According to QS World University ranking, SKKU takes the $162^{\text {nd }}$ position internationally and the 6th nationally in 2013. According to Times Higher Education (THE), the university ranks in the category 201-225 for two consecutive years (2012 and 2013) and according to Academic Ranking of World Universities (ARWU), it ranks in the category of 201-300 for the past two years. ARWU is released by the Center for World-Class Universities at Shanghai Jiao Tong University. The university rankings from several sources for the past two to three years are listed in Table 1. Nowadays, SKKU has five colleges, ten divisions, 17 graduate schools and offers 51 majors (see KCUE [16]). In addition, the university also boasts with 18,000 undergraduate students and 7000graduate students, supported by more than 1000 faculty and 400 administrative staffs. 


\section{Organization of Calculus course}

\subsection{Course management}

Two Calculus courses (Calculus 1 and Calculus 2) are offered as the Basic Science and Mathematics (BSM) modules in the Natural Science Campus at SKKU. Other courses that belong BSM modules amongst others are General Physics 1 and 2, General Chemistry 1 and 2 and General Biology 1 and 2. These BSM modules are offered and organized by the Faculty of Natural Sciences in cooperation with University College and the respective departments related to those courses. A limited number of BSM modules is also offered in the Humanities and Social Science Campus in Seoul. Several faculties who reside in Suwon might need to commute to Seoul if they are assigned to teach in Seoul campus.

The two Calculus courses are by far the largest classes in terms of student's number registered at SKKU. During Fall/Autumn 2010 semester, there were almost 1600 students enrolled in Calculus 2 courses and the majority of them are freshmen. The total of 18 sections are assigned to 12 instructors and one instructor acts as a course coordinator. Fourteen sections have a maximum number of students of 80 pupils and four sections have larger size number of students up to a maximum of 120 pupils. All students would sit for identical examination papers, both for the midterm and the final exams. However, each instructor may have additional assessments, including but not limited to, homework, assignments, group projects or quizzes tailored to his/her own teaching. The students may access the syllabus through intranet university's communication system called icampus (SKKU icampus [34]) as well as the internal registration system known as ASIS-GLS information system.

The semester at SKKU runs for 16 weeks, including a one-week period each for the midterm and the final exams. So, in principle there are only 14 weeks of effective teaching period during the entire semester. Each week teaching session is typically composed of either double one-and-half hour sessions or a single three-hour session, depending on the timetable organized by the Mathematics Department. During intensive semesters (Summer and Winter), the semester is organized in a three-week period, forming it to a total of 15 days which correspond to 15 weeks in a regular semester.

In particular, during Winter 2010 semester, the Department of Mathematics offers two sections of Calculus 2 and two different instructors conduct both classes independently. As a consequence, all exams are not necessarily identical due to this independent nature. Since the intensive semester is relatively short, there are neither graded assignments nor group projects. There exist, however, a few voluntary and ungraded assignments and group projects to gauge the students' interest in learning the content knowledge. 
Similar to the regular semester, the maximum number of students in one class is also limited to a maximum number of 80 pupils.

\subsection{Adopted textbook}

A single textbook is adopted and being used for teaching and learning of Calculus 1 and Calculus 2 courses, both in regular (Spring and Fall/Autumn) as well as during intensive semesters (Winter and Summer). Although there is a plan to adopt a different textbook for Calculus courses starting the new academic year 2011, so far only a particular textbook from Stewart has been used for the two courses, i.e. Stewart [36]. The Korean translation of this very book is also readily available to the students and some of them prefer to read and to study the translated version instead of the original one for a better understanding of the material. It is observed that many students made photocopies of the book instead of purchasing the original version of it. It seems that violating of copyright law is still relatively rampant in this advanced country.

The textbook from Stewart [36] is intended for a year long course, covering both single and multivariable Calculus, including an introduction to Vector Calculus. To obtain a general overview of the syllabus for these two Calculus courses, simply divide the textbook into two parts. Calculus 1 covers Chapter 1 to Chapter 8 and Calculus 2 covers Chapter 9 to Chapter 13 of the textbook. Although more chapters are weighted toward Calculus 1 course, the pace of teaching can be done faster since the students are already knowledgeable with many elements of Calculus from their high school mathematics lessons (Kim et al. [14]. On the other hand, even though only five chapters are covered in Calculus 2, there are occasions that the materials are covered relatively fast and some parts are skipped entirely in order to explain better on other parts, which are rather new to the students. In fact, the course coordinator has provided a detailed syllabus, including the parts that need to be skipped and to be omitted.

The students may access the syllabus through intranet university's communication system called icampus (see SKKU icampus [34]) as well as the internal registration system known as ASIS-GLS information system. Similar to many textbooks for basic courses at the freshman level of undergraduate programmes, the adopted Calculus textbook (Stewart [37]) provides excellent materials for Calculus teaching and learning. It presents a mixed balance of theoretical concepts, worked examples, use of technology and short biographies of several prominent mathematicians who contributed to the development of Calculus. What is very essential for the students is its feature in providing many exercise problems with diverse level of difficulties. The book is intended to be a mainstream Calculus text that is suitable for every kind of course at every level. It is designed particularly for the standard course of two semesters for students majoring in Natural Sciences and Engineering. Certainly, students 
are expected to have some background of high school mathematics in algebra, geometry and trigonometry as a general prerequisite for the course and in order to be able to follow the material in the book. The book also contains many beautiful artworks that give a vivid illustration to the readers when particular concepts are being explained. For every published edition, the author always makes an endeavor to improve the textbook, which includes the mathematical precision, accuracy, clarity of exposition and outstanding examples and problem sets which have also characterized the earlier editions too. The 'focus on problem solving' feature has made the book a favorite among students and instructors in a wide variety of colleges and universities throughout the world.

The applications of Calculus in many diverse fields of study are also presented in an interesting manner. Since the book has a relatively challenging way of presentation, the students who are rather weak in mathematics may have a difficult time following the textbook's rigorous approach and some algebraic or conceptual jumps. The first three editions of the textbook were intended to be a synthesis of Calculus reform and traditional approaches to Calculus instruction. In the fourth edition, the author continues to follow that path by emphasizing conceptual understanding through visual, verbal, numerical and algebraic approaches. The aim is to convey to the students both the practical power of Calculus and the intrinsic beauty of the subject. In whatever teaching approaches that one as an instructor may implement, or in whatever style approach the book might be presented, a common goal remains to be achieved: to enable students to understand and appreciate the beauty of Calculus. Some features of the book consists of conceptual exercises, graded exercise sets, realworld data, applied projects, laboratory projects, writing projects, discovery projects, problem solving, some rigorous proofs and the use of technology.

There are also ancillaries for both the instructors and the students. For instructors, the Power Lecture CD-ROM is provided. This includes lectures in Power Point format and an electronic version of the Instructor's Guide. Apart from this, the instructor also has an access to the accompanying Complete Solutions Manual of the textbook and Tools for Enriching TM Calculus available at www.stewartcalculus.com (Stewart [36]). Ancillaries for students include Stewart Specialty Website (Stewart [36]), Enhanced Web Assign, The Brooks/Cole Mathematics Resource Center Website (Cengage [4]), Maple CDROM, Tools for Enriching CalculusTM, Study Guide for both Single and Multivariable Calculus, Student Solutions Manual and Calc-Labs with Maple and Mathematica.

\section{Calculus teaching and learning}

\subsection{Teacher-oriented teaching and learning}

The teaching method implemented for Calculus courses, and any other mathematics based courses, is generally traditional, conventional and teacheroriented: the instructor acts as the controller of the learning environment 
(Flinders [7]). The instructor of traditional way creates an environment for which the learning process is teacher-centered instead of student-centered (Novak [25]). Thus, in a number of occasions, the teaching session is heavily dominated by merely delivering a lecture to the students with a minimal opportunity for or even no participation at all from the students' side. Nowadays, many experts in education around the world encourage many educators, including school teachers and university instructors to combine teaching methods, if not switching entirely. Non-traditional pedagogical approaches such as problem-based learning and engaging students more by active learning and collaborative team work definitely worth to consider. There is definitely an abundant literature on these topics, amongst others are (Ramsay and Sorrell [28]; Röj-Lindberg [29]; Rosenthal [30], Zhang [40, 41], Zwek [42]).

The fact that many educators suggested to move away the teaching methods from the conventional ones, does not necessarily mean that the traditional teaching method is not useful any longer. Depending on how instructors implement the traditional teaching method, an effective teaching that creates a conductive learning environment and gives an optimal benefit for the students can still be achieved. By having a good preparation, implementing a structured organization, generating an outline, analyzing the audience, choosing examples, choosing learning activities, using audio/visual aids and reviewing the materials, interesting set of lectures can be created using this traditional teaching approach (Rutgers [31]). Although some might believe that nonconventional or modern teaching methods are better than the traditional and conventional ones, alternative methods are equally successful when they are handled in an effective manner.

In Calculus courses, entirely abandoning the traditional and conventional teaching method can be very challenging. However, elements of nonconventional teaching methods can be embedded so that the teaching activities do not only have more variations but also become more interesting for the students. In turn, it is expected that the students will have a voracious appetite in learning and studying.

The Power Lecture CD-ROM from the textbook is fully utilized during the teaching activities. When explaining new concepts, definitions, properties and theorems, the CD-ROM is very useful since it saves time compared to rewriting again everything on the blackboard/whiteboard. The CD-ROM also contains good quality artworks that describe mathematical concepts or threedimensional objects which are not so easy or even impossible to sketch by hand. When discussing examples, the CD-ROM provides a step by step explanation, identical to one found in the textbook. The students can easily lose their attention during lecture, particularly when the lecture slide has been shown for more than 20 minutes. So, instead of directly displaying the step by step explanation from the slide, it is good to explain the students by hand, either by 
writing on the computer screen (projected to a huge screen) or on the whiteboard. By doing this, hopefully we are able to keep the students' attention and to improve their understanding in problem solving. After this step, the students can be inquired whether they have any questions or find any unclear explanation steps. It is a norm culturally that Korean students will keep quiet and will not pose any questions in public, even though they might not fully grasp the entire teaching session. Assigning the students exercise problems from the textbook can maintain a high level of alertness from the students' side.

Every lecture session would be recorded (the so-called e+ lecture), and the recording is uploaded automatically to the icampus system after the teaching session is completed. The recording software does not only capture the explanation from the instructor but also includes the slides and everything written on the computer screen. This is beneficial to the students since they might want to review the lecture again after the class is over in case they find certain concepts are difficult to grasp and the instructor's pace is too fast to follow and yet they are rather shy to ask questions in a public setting or to inquire the instructor to repeat the explanation on certain topics, particularly difficult concepts. The recording is also useful for the students who miss the class during that particular session of the day.

The classrooms used for Calculus 2 classes during Fall/Autumn and Winter 2010 are 31255 and 26515, respectively. Both classrooms are lecture hall type and the desk and chairs are fixed. Unfortunately re-arranging seat, for the sake of some active learning activities, is impossible. Since the students always sit at the back of the classroom or at the far side seats, taking the front and the middle seats is always encouraged. Certainly, it is not ethical to enforce where the students must sit, but it is preferable that as many students as possible use these seats and leave the rest for the latecomers. The response to this admonition is rather poor. Although some students move to the front seats, the majority still remained seated at the rear part of the classroom. Very often, the first two or three rows of the front seats remain empty for the lecture hall 31255 and the first front row remains empty for the lecture hall 26515.

Furthermore, the majority of the student prefers to sit close to their peers whom they already familiar. When the students sign up for a particular course, they may have some discussions and agreements with their peers when choosing a certain lecturer. This may explain why some students prefer to mingle with their peers rather than mix around with other 'non-familiars'. On the other hand, as the semester evolves, some students were making new friends with others whom they did not really know initially. Signing up the class is on the first come first served based. As a consequence, the composition of one class may vary not only on their major study but also according to their level year of study. 


\subsection{Student-oriented teaching and learning}

The student-oriented teaching and learning in Calculus classes has been implemented by active learning strategies. Some of the adopted strategies are question and answer session, peer-tutoring session and team-work project assignment. The students' active participation can be stimulated by posing them several questions during the teaching session and allow them to give responses. For instance, whether intentionally or not, it may happen that some calculation errors occur when solving examples taken from the textbook. The students may or may not be aware of the errors. Even those who are aware, they are hesitant to pinpoint the errors publicly. This situation is a good opportunity to pause and ask them to pinpoint where the errors are. It helps them to think, to stay alert and to be involved during the classroom session.

Another way is by asking one or more students to write and present their work on the whiteboard. From this presentation, the way they present mathematical expressions can be monitored and suggestions for improvement are given. The way they present on the whiteboard generally also reflects the way they write their solutions on the exams. Even if it is no problem for them to verify the correct answers of the odd-numbered questions from the textbook, the presentation of the solutions may need to be improved. Furthermore, many of the students find it difficult to explain their presentation in English even though they can explain comfortably in Korean. So, after the students complete their work on the whiteboard, a further training could be provided by inquiring them some questions of what they have written and let them explain with their own words. It is often discovered that they write certain symbols and yet did not explain what those symbols mean. This training is hopefully useful for them when eventually they have to write their exam papers.

\section{Conclusion}

Although embracing students' participation strategies in the teaching style is an indispensable pedagogy tool, the students' psychology can easily throw a spanner in the works. If the instructor does not specify well-defined regulations for the students' rewards for participating in the activities, students would lose interest and their efforts would diminish as well. The regulations must clearly state what grade incentives students can earn for their participation. Students therefore need to know how this is evaluated and how it affects their grade. Especially students who perform below average seem to need this kind of incentives.

From this study we have seen some anecdotal evidences that students' learning is improved when they are actively engaged with the study material, instead of only sitting passively in the classroom and listening to the lecture. More success can be achieved when the classroom activities are also fun. With a proper balance between lecturing and engaging students new concepts and 
activities, in which students, alone or in groups, need to struggle themselves with these concepts, makes the learning time in the classroom more effective and the time spent in class becomes more enjoyable for the students. Students also show appreciation for this style of teaching. Despite classroom participation and group activities are generally more successful in classes with a small number of students, some promising and good results have been accomplished even though the class sizes were relatively large.

Improving students' participation in Calculus classes has achieved a measure of success to a certain extent. Some students are willing to participate in class activities, but others are still quite hesitant. Because the students' educational backgrounds are diverse, particularly the weaker students should discern how to benefit from classroom participation. Although it is almost impossible to design a teaching style that suits for all students, some student-oriented active learning approaches can be implemented for the future study, including teamwork guided discovery (see Leutner [21], Shrager and Klahr [33]) or problembased learning approach (Hmelo-Silver [8]; Neville [24]). Implementing practical methods that worked out best for the students will be implemented continuously and improved regularly during the coming semesters.

\section{Acknowledgement}

The author acknowledged many fruitful discussions with Rob Lahaye from Physics Department, University College, Natural Science Campus of SKKU and Dan Kim from Center of Teaching and Learning, Humanities and Social Science Campus of SKKU and Educational Broadcasting System (EBS) television as well as SKKU's Academic Affairs Office for a generous financial support through the Undergraduate Educational Policy Development Project

\section{References}

1. Abramovitz, B., Berezina, M.,Koichu, B. and Shvartsman, L., 2010.,Urging Calculus students to be active learners: What works and what doesn't. Proceedings of CERME 6, pp. 2376-85. Lyon, France: INRP.

2. Bonwell, C. and Eison, J., 1991.,Active Learning: Creating Excitement in the Classroom. AEHE-ERIC Higher Education Report Volume1. Washington, D.C.: Jossey-Bass.

3. Carlson, K. A. and Winquist, J. R., 2011., Evaluating an active learning approach to teaching Introductory Statistics: A classroom workbook approach. Journal of Statistics Education 19(1): 1-22.

4. Cengage, 2013.,Cengage publisher's website. Available online at http://www.cengage.com/math. Last accessed on October 17, 2013.

5. CIA., 2002., Central Intelligence Agency The World Factbook's official website. Available online at https://www.cia.gov/library/publications/theworld factbook/fields/2103.html.Last accessed on October 22, 2013. 
6. Eison, J., 1990., Confidence in the classroom: Ten maxims for new teachers. College Teaching 38(1): 21-25.

7. Flinders University website on education. Available online at http://ehlt.flinders.edu.au/education/DLiT/2002/environs/scott/tradteac .htm Last accessed October 17, 2013.

8. Hmelo-Silver, C. E., 2004., Problem-based learning: What and how do students learn? Educational Psychology Review 16(3): 235-266.

9. Hughes-Hallett, D., Lock, P. F., Gleason, A. M., Flath, D. E., Gordon, S. P., Lomen, D. O., Lovelock, D. McCallum, W. G., Osgood, B. G. and Pasquale, A., 2013.,Applied Calculus 2nd edition, Active learning edition. Hoboken, NJ: Wiley.

10. Idris, N., 2009., Enhancing students' understanding in Calculus through writing. International Electronic Journal of Mathematics Education 4(1): 36-55.

11. IEA., 2011., International Association for the Evaluation of Educational Achievement's official website. Available online at http://www.iea.nl/. Last accessed on October 18, 2013.

12. Isaksen, S. G., Parnes, S. J., 1985., Curriculum planning for creative thinking and problem solving. Journal of Creative Behavior 19(1): 1-29.

13. Kim, H. and Kim, M., 2006., The factors stimulating students' willingness participation in an synchronous online discussion. In T. Reeves and S. Yamashita (Eds.), Proceedings of World Conference on e-learning in Corporate Government, Healthcare and Higher Education 2006, pp. 208087. Chesapeake, VA: AACE.

14. Kim, J., Han, I., Park, M. and Lee, J., 2013.,Mathematics Education in Korea: Curricular and Teaching and Learning Practices. Singapore: World Scientific.

15. King, A., 1993., From sage on the stage to guide on the side. College Teaching 41(1): 30-35.

16. KCUE, 2011.,Korean Council for University Education handbook. Gateway to Korean University. Seoul, South Korea: KCUE.

17. Kvam, P. H., 2000., The effect of active learning methods on student retention in Engineering Statistics. The American Statistician 54(2): 136140.

18. Laws, P., Sokoloff, D. and Thornton, R., 1999., Promoting active learning using the results of Physics Education research. UniServe Science News 13: 14-19.

19. Lazarus, J-A., 1999., Stimulating active participation and enhancing critical thinking. Teaching and Learning Excellence. University of Wisconsin at Madison Teaching Academy's website. Available online at https://tle.wisc.edu/forum/stimulating-active-participation-andenhancing-critical-thinking. Last accessed on October 15, 2013.

20. Lee, H-J., 2009., Higher education in Korea. Center for Teaching and Learning Seoul National University.Available online at http://www.eastwestcenter.org/. Last accessed on October 22, 2013. 
21. Leutner, D., 1993.,. Guided discovery learning with computer-based simulation games: Effects of adaptive and non-adaptive instructional support. Learning and Instruction 3(2): 113-132.

22. McKinney, K., 2011., Active learning. Center for Teaching, Learning and Technology, Illinois State University. Available online at www.baruch.cuny.edu/facultyhandbook/documents/ActiveLearning.docx. Last accessed on October 15, 2013.

23. Meyers, C. and Jones, T. B. , 1993.,Promoting active learning\{Strategies for the college classroom. San Francisco, CA: Jossey-Bass Publishers.

24. Neville, A. J., 2009., Problem-based learning and medical education forty years on. A review of its effects on knowledge and clinical performance. Medical Principles and Practice: International Journal of the Kuwait University, Health Science Centre 18(1): 1-9.

25. Novak, J., 2010.,Learning, creating and using knowledge. Concept Maps as facilitative tools in schools and in corporations, 2nd edition. New York, NY: Routledge.

26. OECD., 1961., Organization for Economic Cooperation and Development's official website. Available online at http://www.oecd.org/. Last accessed on October 18, 2013.

27. Parry, Z. and Lee, S. H., 2011., The higher education sector in Korea: What you see is not always what you get. The Observatory on Borderless Higher

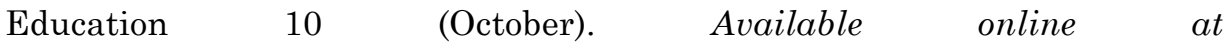
http://www.obhe.ac.uk/newsletters/borderless_report_october_2011/highe r_education_in_south_korea. Last access on October 22, 2013.

28. Ramsay, J. and Sorrell, D., 2006., Problem-based learning: A novel approach to teaching safety, health and environmental courses. Journal of SH\&E Research 3(2): 1-8.

29. Röj-Lindberg, A., 2001., Active learning of mathematics. In Benton, N \& R. (Eds.) TeRito o the Matauranga: Experiential Learning for the Third Millenium. 2: 159-168. Auckland, New Zealand:James Henare Maori Research Centre for the International Consortium for Experiential Learning.

30. Rosenthal, J. S., 1995., Active-learning strategies in advanced mathematics classes. Studies in Higher Education 20: 223-228

31. Rutgers University's Center for Teaching Excellence's website. Available online at http://cte.umdnj.edu/. Last accessed October 18, 2013.

32. Salter, D., 2010.,Practical Strategies for Implementing Problem-Based Learning. Center for Teaching and Learning, Seoul, South Korea: SKKU.

33. Shrager, J. and Klahr, D., 1986.,Instructionless learning about a complex device: the paradigm and observations. International Journal of ManMachine Studies 25: 153-198.

34. SKKU, 2013., Sungkyunkwan University's official website in English. Available online at http:// www.skku.edu/eng/. Last accessed on October 15, 2013.

35. Sungkyunkwan University's icampus website. Available online at http://www.icampus.ac.kr/. Last accessed on October 22, 2013. 
36. Stewart, J., 2005., Website of the author's textbooks. Available online at http://www.stewartcalculus.com/. Last accesses on October 17, 2013.

37. Stewart, J., 2010.,Calculus Concepts and Contexts. Metric International Edition (4th edition). Belmont,CA: Brooks/Cole Cengage Learning.

38. Weiner, M. and Kelly, R. (Eds.), 2012., Active learning: Changed attitudes and improved performance. The Teaching Professor 26(3): 3.

39. Wikipedia article on Sungkyunkwan University. Available online at http://en.wikipedia.org/wiki/Sungkyunkwan_University. Last accessed on October 15, 2013.

40. Zhang, X., 2002., The combination of traditional teaching method and problem based learning. The China Papers 1: 30-36.

41. Zhang, B., 2003., Using student-centered teaching strategies in Calculus. The China Papers 2: 100-103.

42. Zwek, J., 2006., Strategies to promote active learning in Math/Statdiscussion sessions. Available online at http://www.math.umbc.edu/ zweck/TATrain/ActiveLearningStrategies.p df. Last accessed October 17, 2013. 